\title{
Diazotrophic population and soil nitrogen dynamics following coapplication of biochar with inorganic fertilizer in the humid tropics
}

\author{
Muhammad Farid Azlan Halmi1,2 (D), Khanom Simarani²,* (D) \\ 1. University of Malaya - Faculty of Science - Institute of Biological Sciences, Division of Microbiology - Kuala Lumpur, Malaysia. \\ 2. Department of Chemistry Malaysia - Kota Kinabalu (Sabah), Malaysia. \\ Received: Jan. 16, 2021 | Accepted: May 3, 2021 \\ Section Editor: Hector Valenzuela \\ *Corresponding author: hanom_ss@um.edu.my \\ How to cite: Halmi, M. F. A. and Simarani, K. (2021). Diazotrophic population and soil nitrogen dynamics following coapplication of biochar \\ with inorganic fertilizer in the humid tropics. Bragantia, 80, e3521. https://doi.org/10.1590/1678-4499.20210017
}

\begin{abstract}
Nutrient loss from the weathering process is a major challenge for tropical agriculture. Biochar with nutrient retention capacity has been proposed as an amendment to retain plant-available nutrients. Meanwhile, information on diazotrophic population responses to biochar application in the humid tropics is still poorly explored. A field study was carried out over three cropping cycles of maize in a typic paleudults of Peninsular Malaysia. During the first cropping cycle, the soil was amended with palm kernel shell biochar (PK), rice husk biochar $(\mathrm{RH})$, palm kernel biochar with fertilizer (FPK), rice husk biochar with fertilizer (FRH), fertilizer (F), and control soil (C). Soil samples were taken at each harvesting stage and analyzed for $\mathrm{pH}$, cation exchange capacity $(\mathrm{CEC})$, total $\mathrm{N}$, ammonium $\left(\mathrm{NH}_{4}{ }^{+}-\mathrm{N}\right)$, nitrate $^{-}\left(\mathrm{NO}_{3}{ }^{-}-\mathrm{N}\right)$, microbial biomass $\mathrm{N}$, and urease activity. Total and active diazotrophs were quantified from soil DNA and RNA, respectively, employing quantitative polymerase chain reaction (qPCR) amplification of the nifH gene. Palm kernel shell and rice husk biochars maintained a significant $\mathrm{NH}_{4}{ }^{+}-\mathrm{N}$ and $\mathrm{NO}_{3}{ }^{-}-\mathrm{N}$, respectively, during the second cropping cycle. Both biochars promote the total and active diazotrophic population. A detrimental impact on the nifH transcript was detected from fertilization even when biochar was co-amended. Two possible land management options for tropical soil were proposed from the overall data. First, the application of fertilizer with biochar can reduce $\mathrm{N}$ loss against weathering. Second, the application of biochar alone may improve biological $\mathrm{N}_{2}$ fixation in tropical soils.
\end{abstract}

Key words: active microbial population, microbial soil enzyme, highly weathered soil, nifH, nitrogen retention, qPCR.

\section{INTRODUCTION}

The acidic soil in the humid tropics is naturally deficient in plant nutrients due to high weathering in this climatic region. Intense weathering from continuous high rainfall constrains crop production by causing rapid $\mathrm{N}$ loss from the soil through leaching and surface run-off. Consequently, regular fertilization has been a common practice to substitute $\mathrm{N}$ loss in the soil (Moura et al. 2016). However, frequent fertilization is still considered ineffective and uneconomical as the fertilizer applied may still be lost due to the natural weathering process. High dependency on $\mathrm{N}$ fertilizer and its excessive application may also cause detrimental environmental impacts, such as ammonia volatilization and eutrophication via nitrate leaching (Moura et al. 2016).

Recently, a growing body of evidence supports the application of biochar, a thermal degradation organic product from pyrolysis (Lehmann et al. 2011), as an amelioration solution for the problematic highly weathered soil in the humid tropics. Many field trials demonstrate significant enhancement in soil properties (Oladele et al. 2019a; Simarani et al. 2018) and agronomic production (Hale et al. 2020; Halmi et al. 2018) by treating tropical soil with this pyrogenic organic carbon. Supplementation of biochar with fertilizer may further enhance the amelioration effect, as biochar can hold the applied $\mathrm{N}$ and prevent it from leaching (Oladele et al. 2019a; Uttran et al. 2018), and hence, mitigate $\mathrm{N}$ loss against weathering. 
A growing body of evidence reveals that biochar induces soil microbiota responses (Lehmann et al. 2011), including in the humid tropics (Halmi and Simarani 2021; Oladele 2019b; Petter et al. 2019). Stimulation of biological $\mathrm{N}_{2}$ fixation by diazotrophs upon biochar treatment is another beneficial biochar effect (Liu et al. 2018; Xiao et al. 2019). Diazotrophs, either symbiotic or free-living, play an essential role in soil $\mathrm{N}$-cycling by fixing atmospheric $\mathrm{N}_{2}$ to plant-available $\mathrm{N}$ form (Poly et al. 2001), mediated by reduction activity of the nitrogenase enzyme. Investigation of diazotrophs abundance in the terrestrial ecosystem has primarily relied on quantifying the nifH gene as a molecular marker (Reed et al. 2011), which encodes the nitrogenase enzyme. Although the study of the diazotrophic population has been reported in biochar amended soil, the information of their response, particularly in the humid tropical region, is still poorly explored. In view of that, the assessment of diazotrophic response to biochar treatment in the humid tropics is essential to fill the gap on the regional scale. Understanding the dynamics of the total and active diazotrophic population in the tropical agroecosystem may also help to design $\mathrm{N}$ management approaches for sustainable agriculture.

This field study aimed to verify the impacts of two contrasting biochars supplemented with or without NPK fertilizer on the diazotrophic population and soil $\mathrm{N}$ dynamics over three cropping cycles in soils of the humid tropics. It was hypothesized that; 1 ) the treatment with biochar in the tropical soil would modify the status of soil $\mathrm{N}$ and diazotrophic populations, and; 2) the variation would differ subject to the type of biochar amended and fertilizer supplementation.

\section{MATERIAL AND METHODS}

\section{Study site, experimental design, and soil sampling}

The study site was situated at Jelebu, Negeri Sembilan, Malaysia $\left(3^{\circ} 03^{\prime} \mathrm{N}, 102^{\circ} 03^{\prime} \mathrm{E}\right)$. The site has a tropical rainforest climate with annual precipitation of $2500 \mathrm{~mm}$, a mean temperature of $27^{\circ} \mathrm{C}$, and daily sunshine of $12 \mathrm{~h}$. The highly weathered soil was classified as typic paleudults with a sandy loam texture. The soil had an initial pH of $4.98,5.11 \mathrm{~g} \mathrm{C}^{\mathrm{kg}}{ }^{-1}$ soil, and $0.6 \mathrm{~g} \mathrm{~N} \cdot \mathrm{kg}^{-1}$ soil to a soil depth of $20 \mathrm{~cm}$. Two contrasting biochars of different feedstock and pyrolysis conditions were used for amendment. The palm kernel shell and rice husk biochar used were locally made by the Malaysian Palm Oil Board (MPOB) and Padiberas Nasional Berhad (BERNAS), respectively. The properties of these biochars were previously characterized (Simarani et al. 2018) and are summarized in Table 1.

Table 1. Selected properties of palm kernel shell and rice husk biochars used for soil amendment (Simarani et al. 2018).

\begin{tabular}{lcc}
\hline Properties & Palm kernel shell biochar & Rice husk biochar \\
\hline Production process & Slow pyrolysis at $400{ }^{\circ} \mathrm{C}$ & Gasification at $800{ }^{\circ} \mathrm{C}$ \\
\hline $\mathrm{pH}$ & 8.67 & 10.24 \\
\hline Total $\mathrm{C}\left(\mathrm{g} \cdot \mathrm{kg}^{-1}\right)$ & 434.1 & 101.7 \\
\hline Total $\mathrm{N}\left(\mathrm{g} \cdot \mathrm{kg}^{-1}\right)$ & 5.07 & 2.52 \\
\hline Total $\mathrm{P}\left(\mathrm{g} \cdot \mathrm{kg}^{-1}\right)$ & 1.56 & 2.11 \\
\hline $\mathrm{C}: \mathrm{N}$ & 85.62 & 40.37 \\
\hline $\mathrm{NH}_{4}{ }^{+}-\mathrm{N}\left(\mathrm{mg}^{\left.-\mathrm{kg}^{-1}\right)}\right.$ & 21.05 & 25.48 \\
\hline $\mathrm{NO}_{3}^{-}-\mathrm{N}\left(\mathrm{mg}^{-1} \mathrm{~kg}^{-1}\right)$ & 40.88 & 92.17 \\
\hline Ash $\left(\mathrm{g} \cdot \mathrm{kg}^{-1}\right)$ & 180 & 750 \\
\hline $\mathrm{BET}$ surface area $\left(\mathrm{m}^{2} \cdot \mathrm{g}^{-1}\right)$ & 184.2 & 1.6 \\
\hline Particle size range $(\mathrm{mm})$ & $5-10$ & $1-3$ \\
\hline
\end{tabular}

Three consecutive cultivation cycles of maize (Zea mays 'Masmadu') in the field were carried out from September 2015 until October 2016. Maize was sown in early September 2015, February 2016, and July 2016. The following treatments with four replications on a completely randomized block design plot of $4 \times 4 \mathrm{~m}^{2}$ were applied once in September 2015 . The treatments were 1) soil amended with palm kernel shell biochar (PK);2) soil amended with rice husk biochar (RH); 
3) soil amended with palm kernel shell biochar incorporated with NPK fertilizer (FPK); 4) soil amended with rice husk biochar incorporated with NPK fertilizer (FRH); 5) soil amended with NPK fertilizer (F), and; 6) soil without treatment as a control (C). Amendment rates were based on recommendations by the Malaysian Agricultural Research and Development Institute (MARDI) for the Masmadu cultivar. Biochar was amended as top-dressing at $20 \mathrm{Mg} \cdot \mathrm{ha}^{-1}$ rate of application. The fertilizer added comprised $60 \mathrm{~kg} \mathrm{~N} \cdot \mathrm{ha}^{-1}, 26.2 \mathrm{~kg} \mathrm{P} \cdot \mathrm{ha}^{-1}$, and $33.2 \mathrm{~kg} \mathrm{~K} \cdot \mathrm{ha}^{-1}$ from urea, triple phosphate, and muriate of potash, respectively. No additional application of biochar or chemical fertilization was made for the subsequent cropping cycles.

Sampling was done during each harvest cycle of maize in December 2015, May 2016, and October 2016 after 3 months $\left(_{3 \mathrm{M}}\right)$, 7 months $\left({ }_{7 \mathrm{M}}\right)$, and 13 months $\left({ }_{13 \mathrm{M}}\right)$ of field exposure, respectively (the specific treatment plots of different cycles is hereafter referred to as their treatment abbreviations with the time of field exposure subscripted). Five random sites $(0-20 \mathrm{~cm}$ depth) in each plot were sampled using a one-piece Edelman auger ( $7 \mathrm{~cm}$, Eijkelkamp, The Netherlands). All five sub-soil samples from each plot were mixed to obtain a composite sample.

\section{Soil physical and chemical properties}

Soil $\mathrm{pH}$ was measured using soil-deionized water suspension in the ratio of 1:2.5. Cation exchange capacity (CEC) of sample soil was determined by the $\mathrm{BaCl}_{2}$ compulsive exchange method (Gillman and Sumpter 1986). Total soil $\mathrm{N}$ was measured using the TruSpec Micro CHN analyzer (LECO, USA). Analysis of soil ammonium, $\mathrm{NH}_{4}^{+}-\mathrm{N}$, and nitrate, $\mathrm{NO}_{3}^{-}{ }^{-} \mathrm{N}$, was done in a QuikChem 8500 Series 2 Flow Injection Analysis System (Hach, USA) at 660 and $520 \mathrm{~nm}$ wavelengths, respectively.

\section{Soil microbial biomass $\mathrm{N}$}

Total microbial biomass was extracted by the fumigation-extraction method (Vance et al. 1987). A portion of moist soil was fumigated with an ethanol-free $\mathrm{CH}_{3} \mathrm{Cl}$ in a vacuum desiccator for $24 \mathrm{~h}$ at $25^{\circ} \mathrm{C}$. Fumigated and an equal portion of nonfumigated soils were extracted with $0.5 \mathrm{M} \mathrm{K}_{2} \mathrm{SO}_{4}$ on a 1:4 ratio of soil to extractant. The extracted solution was filtrated with Whatman No. 42 filter paper. Microbial biomass N was determined from the filtrate by persulfate digestion (Doyle et al. 2004).

\section{Soil urease assay}

Assay for soil urease (EC 3.5.1.5) activity was done colorimetrically (Kandeler and Gerber 1988) using urea as a substrate at an incubation temperature of $37^{\circ} \mathrm{C}$ for $2 \mathrm{~h}$. Ammonium moiety released from the enzymatic reaction was measured using a V-630 spectrophotometer (Jasco, The Netherlands) at $690 \mathrm{~nm}$ wavelength.

\section{Nucleic acids extraction and qPCR}

Total soil DNA and RNA were simultaneously extracted using NucleoBond Soil (MACHEREY-NAGEL, Germany) by following the manufacturer's protocol. The integrity of nucleic acids extracted was assessed through agarose gel electrophoresis and Nanodrop 2000 UV-Vis spectrophotometer (Thermo Scientific, USA). The extracted RNA was reverse transcribed to synthesize cDNA using a SensiFAST cDNA Synthesis Kit (Bioline, UK).

Absolute quantification of nifH genes (DNA-derived) and transcripts (RNA-derived) were conducted in a QuantStudio 12K Flex Real-Time PCR System (Applied Biosystems, USA). The amplification was performed using the degenerate primer set nifH-F (5'-AAA GGY GGW ATC GGY AAR TCC ACC AC-3') and nifH-R (5'-TTG TTS GCS GCR TAC ATS GCC ATC AT-3') (Rösch et al. 2002). Each reaction tube consisted of $8 \mu \mathrm{L}$ nucleic acid template, $0.4 \mu \mathrm{mol} \cdot \mathrm{L}^{-1}$ of each primer, and $10 \mu \mathrm{L}$ of SensiFAST SYBR Lo-ROX Kit (Bioline, UK) in a final reaction volume of $20 \mu \mathrm{L}$. Amplification was done with thermal condition of activation at $95^{\circ} \mathrm{C}$ for $2 \mathrm{~min}$, following 40 cycles of denaturation at $95^{\circ} \mathrm{C}$ for $10 \mathrm{~s}$, annealing at $60^{\circ} \mathrm{C}$ for $10 \mathrm{~s}$, and extension at $72{ }^{\circ} \mathrm{C}$ for $20 \mathrm{~s}$. The specificity of the qPCR amplification was firstly confirmed by melting curve analysis. Standard curves were constructed using a tenfold dilution of known nifH copy numbers amplified from Klebsiella pneumoniae in triplicate $\left(\mathrm{R}^{2}\right.$ value $\left.>0.99\right)$. 


\section{Statistical analysis}

The normality of data was tested using the Shapiro-Wilk test before conducting a parametric test. The difference between treatments was examined by performing a one-way analysis of variance. Data that was statistically significant was subjected to Tukey's range test at $\mathrm{p}<0.05$. Pearson's coefficient test was conducted to identify the correlation between the soil and microbial parameters. All analyses were conducted using XLSTAT (Addinsoft, USA) statistical software.

\section{RESULTS AND DISCUSSION}

\section{Modification of soil physicochemical properties}

Table 2 presents the data on soil physicochemical properties. The $\mathrm{pH}$ and CEC values in all soils treated with biochar were higher than values obtained from all control soils (both at $\mathrm{p}<0.01$ ). However, no difference between these two properties was found between the types of biochar applied ( $p>0.05$ ). Supplementation of fertilizer in the FPK and FRH plots did not affect soil $\mathrm{pH}$ and CEC values from the biochar without fertilizer treatment plots throughout the three cropping cycles. The simultaneous enhancement of $\mathrm{pH}$ and CEC is expected as it is frequently reported by various recent field studies (Hale et al. 2020; Halmi et al. 2018; Oladele et al. 2019a) on the amelioration effect of biochar in the humid tropics.

Table 2. Mean values of soil physicochemical properties, microbial biomass $N$ and urease activity in all treatments at $3\left({ }_{3 M}\right), 7\left({ }_{7 M}\right)$ and 13 months $(13 \mathrm{M})$ of field exposure.

\begin{tabular}{|c|c|c|c|c|c|c|c|}
\hline Treatment & $\mathrm{pH}$ & $\begin{array}{c}\text { CEC } \\
\left.\text { (cmolc } \cdot \mathrm{kg}^{-1} \text { soil }\right)\end{array}$ & $\begin{array}{c}\text { Total N } \\
\left(\mathbf{g} \cdot \mathrm{kg}^{-1} \text { soil }\right)\end{array}$ & $\begin{array}{c}\mathrm{NH}_{4}^{+}-\mathrm{N} \\
\left(\mathbf{m g} \cdot \mathbf{k g}^{-1} \text { soil }\right)\end{array}$ & $\begin{array}{c}\mathrm{NO}_{3}^{-}-\mathrm{N} \\
\left(\mathrm{mg} \cdot \mathrm{kg}^{-1} \text { soil }\right)\end{array}$ & $\begin{array}{c}\text { Microbial } \\
\text { biomass } \mathrm{N} \\
\left(\mathrm{mg} \cdot \mathrm{kg}^{-1} \text { soil) }\right.\end{array}$ & $\begin{array}{c}\text { Urease } \\
\left(\mu \mathrm{mol} \mathrm{N} \cdot \mathrm{kg}^{-1} \text { soil }^{-1} \mathbf{h}^{-1}\right)\end{array}$ \\
\hline \multicolumn{8}{|c|}{ First cropping cycle } \\
\hline $\mathrm{PK}_{3 \mathrm{M}}$ & $6.31 \pm 0.05 a$ & $4.94 \pm 0.38 a$ & $1.07 \pm 0.11 b$ & $12.03 \pm 1.07 b$ & $22.04 \pm 1.22 b$ & $23.33 \pm 4.01 b$ & $2.13 \pm 0.05 b$ \\
\hline $\mathrm{RH}_{3 \mathrm{M}}$ & $6.21 \pm 0.04 a$ & $4.88 \pm 0.21 a$ & $1.23 \pm 0.15 a b$ & $12.53 \pm 0.94 b$ & $28.11 \pm 1.72 \mathrm{ab}$ & $21.68 \pm 2.35 b$ & $2.26 \pm 0.11 b$ \\
\hline $\mathrm{FPK}_{3 \mathrm{M}}$ & $6.18 \pm 0.05 a$ & $4.93 \pm 0.12 a$ & $1.31 \pm 0.13 a$ & $14.47 \pm 1.24 a$ & $23.33 \pm 1.05 b$ & $38.34 \pm 2.36 a$ & $2.87 \pm 0.12 a b$ \\
\hline $\mathrm{FRH}_{3 \mathrm{M}}$ & $6.14 \pm 0.16 a$ & $4.89 \pm 0.11 a$ & $1.38 \pm 0.09 a$ & $14.15 \pm 1.19 a$ & $36.42 \pm 1.86 a$ & $36.71 \pm 4.71 a$ & $3.01 \pm 0.07 a b$ \\
\hline $\mathrm{F}_{3 \mathrm{M}}$ & $5.03 \pm 0.24 b$ & $4.21 \pm 0.11 b$ & $1.33 \pm 0.17 a$ & $14.52 \pm 1.04 a$ & $21.74 \pm 1.09 b$ & $26.67 \pm 4.22 b$ & $3.34 \pm 0.07 a$ \\
\hline $\mathrm{C}_{3 \mathrm{M}}$ & $4.97 \pm 0.19 b$ & $4.11 \pm 0.17 \mathrm{~b}$ & $0.61 \pm 0.09 c$ & $9.86 \pm 0.81 c$ & $16.93 \pm 1.53 c$ & $8.33 \pm 1.93 c$ & $2.46 \pm 0.11 b$ \\
\hline \multicolumn{8}{|c|}{ Second cropping cycle } \\
\hline $\mathrm{PK}_{7 \mathrm{M}}$ & $6.25 \pm 0.03 a$ & $4.81 \pm 0.22 a$ & $1.13 \pm 0.12 b$ & $11.43 \pm 0.86 b$ & $20.72 \pm 1.62 b$ & $25.36 \pm 2.56 b$ & $2.28 \pm 0.12$ \\
\hline $\mathrm{RH}_{7 \mathrm{M}}$ & $6.04 \pm 0.11 a$ & $4.76 \pm 0.19 a$ & $1.22 \pm 0.18 a b$ & $11.72 \pm 0.92 b$ & $26.21 \pm 1.93 b$ & $24.19 \pm 2.78 b$ & $2.54 \pm 0.06$ \\
\hline $\mathrm{FPK}_{7 \mathrm{M}}$ & $6.13 \pm 0.07 a$ & $4.61 \pm 0.24 a$ & $1.27 \pm 0.17 a b$ & $13.95 \pm 1.15 a$ & $21.64 \pm 0.96 b$ & $23.42 \pm 2.33 b$ & $2.24 \pm 0.11$ \\
\hline $\mathrm{FRH}_{7 \mathrm{M}}$ & $6.28 \pm 0.02 a$ & $4.79 \pm 0.23 a$ & $1.32 \pm 0.13 a$ & $12.53 \pm 1.04 b$ & $32.16 \pm 2.02 a$ & $25.82 \pm 3.24 b$ & $2.23 \pm 0.07$ \\
\hline $\mathrm{F}_{7 \mathrm{M}}$ & $5.16 \pm 0.04 b$ & $4.06 \pm 0.12 b$ & $0.71 \pm 0.08 c$ & $9.72 \pm 0.87 c$ & $15.32 \pm 1.73 c$ & $9.12 \pm 2.01 \mathrm{c}$ & $2.64 \pm 0.05$ \\
\hline $\mathrm{C}_{7 \mathrm{M}}$ & $5.23 \pm 0.08 b$ & $4.03 \pm 0.13 b$ & $0.64 \pm 0.11 c$ & $9.63 \pm 1.01 c$ & $14.87 \pm 1.08 \mathrm{c}$ & $8.64 \pm 2.18 c$ & $2.21 \pm 0.07$ \\
\hline \multicolumn{8}{|c|}{ Third cropping cycle } \\
\hline $\mathrm{PK}_{13 \mathrm{M}}$ & $6.15 \pm 0.06 a$ & $4.89 \pm 0.21 a$ & $1.04 \pm 0.09 b$ & $11.33 \pm 1.08 b$ & $25.58 \pm 2.09 b$ & $22.81 \pm 3.02 b$ & $2.18 \pm 0.13$ \\
\hline $\mathrm{RH}_{13 \mathrm{M}}$ & $6.26 \pm 0.09 a$ & $4.68 \pm 0.19 a$ & $1.17 \pm 0.13 b$ & $11.31 \pm 0.94 b$ & $26.04 \pm 1.87 \mathrm{~b}$ & $23.02 \pm 2.73 b$ & $2.43 \pm 0.07$ \\
\hline $\mathrm{FPK}_{13 \mathrm{M}}$ & $6.05 \pm 0.06 a$ & $4.73 \pm 0.24 a$ & $1.11 \pm 0.07 \mathrm{~b}$ & $11.27 \pm 1.14 b$ & $20.93 \pm 1.66 b$ & $27.69 \pm 2.65 b$ & $2.68 \pm 0.11$ \\
\hline $\mathrm{FRH}_{13 \mathrm{M}}$ & $6.24 \pm 0.03 a$ & $4.84 \pm 0.15 a$ & $1.25 \pm 0.11 b$ & $11.54 \pm 1.23 b$ & $24.45 \pm 1.26 b$ & $24.77 \pm 2.54 b$ & $2.29 \pm 0.09$ \\
\hline $\mathrm{F}_{13 \mathrm{M}}$ & $5.23 \pm 0.05 b$ & $4.12 \pm 0.11 b$ & $0.63 \pm 0.09 c$ & $9.34 \pm 0.86 c$ & $15.91 \pm 1.34 c$ & $8.43 \pm 2.13 c$ & $2.52 \pm 0.07$ \\
\hline $\mathrm{C}_{13 \mathrm{M}}$ & $5.09 \pm 0.03 b$ & $4.05 \pm 0.14 b$ & $0.68 \pm 0.07 c$ & $9.27 \pm 0.91 c$ & $16.07 \pm 1.18 c$ & $8.74 \pm 1.95 c$ & $2.32 \pm 0.11$ \\
\hline
\end{tabular}

Note. $\mathrm{PK}=$ palm kernel biochar; $\mathrm{RH}=$ rice husk biochar; $\mathrm{FPK}=$ fertilizer + palm kernel biochar; $\mathrm{FRH}=$ fertilizer + rice husk biochar; $\mathrm{F}=$ fertilizer; $\mathrm{C}=\mathrm{control}$. Mean values followed by different letters within a cropping cycle are statistically different at $\mathrm{p}<0.05$ by Tukey's range test. 
The elevation of $\mathrm{pH}$ in acidic tropical soils is attributed primarily to the liming effect of alkaline biochar. The increasing temperature during biochar production has been linked with increased ash content in biochar products with higher $\mathrm{pH}$ (Tomczyk et al. 2020). For instance, the rice husk biochar used in this study was produced at a higher temperature $\left(800{ }^{\circ} \mathrm{C}\right)$ than the palm kernel shell biochar $\left(400^{\circ} \mathrm{C}\right)$ with higher ash content and $\mathrm{pH}$ value (Table 1). Nonetheless, upon the field application, the difference in soil $\mathrm{pH}$ between both biochars is not significant (Table 2). Interestingly, Table 2 shows that, at both first and second cycles, the palm kernel shell biochar treatment had a slightly higher $\mathrm{pH}$, even though the raw rice husk biochar had an original greater $\mathrm{pH}$ (Table 1). One of the possible explanations for this is that the palm kernel shell biochar applied had a greater number of negatively charged surface functional groups (i.e., hydroxyl, carboxyl, phenolic stretching) than the rice husk biochar (Simarani et al. 2018), which contributes to the basic cation holding potential of biochar. The presence of these groups in both biochars may form bonding with the $\mathrm{H}^{+}$ions, thus lowering the $\mathrm{H}+$ concentration and resulting in the $\mathrm{pH}$ elevation. The augmentation of these negatively charged functional groups in the soil results in a parallel increase in soil CEC, which later may improve the binding of soil cations (Hailegnaw et al. 2019).

The amendment with biochar significantly improved the soil total $\mathrm{N}(\mathrm{p}<0.05)$ compared to the control. The coapplication of fertilizer with biochar showed a trend to increase the total $\mathrm{N}$ further. However, the difference was insignificant in the pair-wise comparison of biochar with or without NPK supplementation. The soil $\mathrm{NH}_{4}{ }^{+}-\mathrm{N}$ was increased $(\mathrm{p}<0.05)$ with biochar addition. The addition of fertilizer with biochar increased the $\mathrm{NH}_{4}{ }^{+}-\mathrm{N}$ levels compared to biochar alone during the first crop cycle. The $\mathrm{NH}_{4}^{+}-\mathrm{N}$ content in all plots treated with biochar, with or without fertilizer, gradually declined over the three maize cultivation cycles, for all treatments. The decrease in $\mathrm{NH}_{4}{ }^{+}-\mathrm{N}$, however, is not statistically different compared to the control soil. In the second cropping cycle, $\mathrm{FPK}_{7 \mathrm{M}}$ displayed a strong residual effect on soil $\mathrm{NH}_{4}^{+}-\mathrm{N}$, maintaining a higher content than the other plots in the second cycle, while $\mathrm{F}_{7 \mathrm{M}}$ became insignificant compared to the untreated plot. For soil $\mathrm{NO}_{3}^{-}-\mathrm{N}$ content, the $\mathrm{RH}_{7 \mathrm{M}}$ recorded a higher value $(\mathrm{p}<0.05)$ than $\mathrm{PK}_{7 \mathrm{M}}$. Here, the residual coapplication effect of biochar and fertilizer is observed during the second cycle, where $\mathrm{FRH}_{7 \mathrm{M}}$ maintained a higher $\mathrm{NO}_{3}^{-}-\mathrm{N}(\mathrm{p}<0.05)$ compared to the other plots. A significant $\mathrm{NO}_{3}^{-}-\mathrm{N}$ reduction was observed in $\mathrm{F}$ plots on the next two subsequent crop cycles. These findings are in agreement with those of previous biochar field studies, which reported the retention of $\mathrm{NH}_{4}^{+}-\mathrm{N}$ (Alling et al. 2014) and $\mathrm{NO}_{3}^{-}-\mathrm{N}$ (Oladele et al. 2019a) in the humid tropics.

Inorganic fertilizer application increased the $\mathrm{N}$ pool of the tested tropical soil in the first cycle. The subsequent decline of total $\mathrm{N}, \mathrm{NH}_{4}^{+}-\mathrm{N}$, and $\mathrm{NO}_{3}{ }^{-} \mathrm{N}$ in the next cropping cycles $\left(\mathrm{F}_{7 \mathrm{M}}\right.$ and $\left.\mathrm{F}_{13 \mathrm{M}}\right)$ suggested that $\mathrm{N}$ applied is lost from the soil due to natural weathering. The palm kernel shell and rice husk biochar demonstrated the retaining potential of applied $\mathrm{N}$ by holding a substantial amount of $\mathrm{NH}_{4}^{+}-\mathrm{N}$ and $\mathrm{NO}_{3}{ }^{-} \mathrm{N}$, respectively, during the second cropping cycle (Table 2). Therefore, this may permit a greater opportunity for plant uptake of these two available $\mathrm{N}$ sources, hence, enhancing crop potential. The retention of these two nitrogenous nutrients suggest that biochar applications could improve fertilization efficacy and hinder $\mathrm{N}$ loss from weathering.

Retention of $\mathrm{NH}_{4}{ }^{+}-\mathrm{N}$ in $\mathrm{FPK}_{7 \mathrm{M}}$ during the second cycle can be attributed to negatively charged functional groups on the biochar surfaces. The palm kernel shell biochar used in this study had a greater number of the negatively charged functional groups - hydroxyl, carboxyl, alkyl - associated with cationic nutrient holding ability compared to rice husk biochar (Simarani et al. 2018), hence, likely had an enormous adsorption potential for $\mathrm{NH}_{4}^{+}-\mathrm{N}$ (Uttran et al. 2018). Simultaneously, biochar produced at a lower temperature, as the palm kernel shell biochar $\left(400^{\circ} \mathrm{C}\right)$, is known to have a higher capacity for cation exchange of basic nutrients (Tomczyk et al. 2020). For instance, Gaskin et al. (2008) demonstrated a reduction of surface functional groups indicative of CEC with increased pyrolysis temperature. The decrease in these functional groups on biochar surfaces can be ascribed to aromatic carbon formation with increasing temperature (Gaskin et al. 2008).

The increase of $\mathrm{NO}_{3}^{-}-\mathrm{N}$ concentration in the $\mathrm{FRH}$ plot during the first two cropping cycles is likely due to the higher initial content of $\mathrm{NO}_{3}^{-}-\mathrm{N}$ from the biochar itself (Table 1). On the other hand, the rice husk biochar used in this study was produced at a higher temperature $\left(800^{\circ} \mathrm{C}\right)$ than the palm kernel shell biochar. A comparative review of available literature by Clough et al. (2013) shows that biochar produced at temperature greater than $600^{\circ} \mathrm{C}$ had a significant $\mathrm{NO}_{3}-\mathrm{N}$ adsorption potential that may protect $\mathrm{NO}_{3}^{-}-\mathrm{N}$ against leaching from the soil. Direct binding of $\mathrm{NO}_{3}^{-}-\mathrm{N}$ with negatively 
charged functional groups on the biochar surfaces is implausible due to surface charged repulsion. A possible adsorption mechanism of $\mathrm{NO}_{3}^{-}-\mathrm{N}$ anion is via cationic bridging of $\mathrm{NO}_{3}^{-}-\mathrm{N}$ to oxidized sites formed by cations bound to the negatively charged oxygenated biochar surfaces, as proposed by Sanford et al. (2019). The increasing pyrolysis temperature is found to accumulate a greater amount of these oxygenated functional groups.

This study provides insight into the nutrient-holding capacity of biochar in the humid tropics. Palm kernel shell and rice husk biochars can maintain a significant amount of $\mathrm{NH}_{4}{ }^{+}-\mathrm{N}$ and $\mathrm{NO}_{3}^{-}-\mathrm{N}$, respectively, following the incorporation of fertilizer. This information implied that fertilizer application efficiency could be improved by co-amending biochar together with the fertilization regime to prevent nitrogenous nutrient losses from the weathering process.

\section{Effect on soil microbial biomass and urease activity}

The three cropping cycles showed that the biochar amendments impacted soil microbial biomass $\mathrm{N}$ (Table 2). The co-amendments of biochar and fertilizer also stimulated soil microbial biomass $\mathrm{N}(\mathrm{p}<0.01)$. There were no differences in microbial biomass $\mathrm{N}$ between the two biochar types. Fertilizer incorporation with both biochars elevated the size of microbial biomass $\mathrm{N}$ further during the first cycle. Fertilizer addition alone increased microbial biomass $\mathrm{N}$ only on the first crop cycle $(\mathrm{p}<0.01)$, with no effects on the next subsequent cycles. The data analysis in Table 3 points out a strong correlation between total $\mathrm{N}$ input with the soil microbial biomass $\mathrm{N}$ pool $(\mathrm{r}=0.9177, \mathrm{p}<0.01)$. A high soil microbial biomass $\mathrm{N}$ may indicate $\mathrm{N}$ immobilization by microbial population, which may restrict $\mathrm{N}$ availability to the plant. However, the microbial biomass $\mathrm{N}$ value alone does not necessarily point out $\mathrm{N}$ deficiency due to immobilization, and hence, the low microbial biomass $\mathrm{N}$ pool in the control plot does not indicate $\mathrm{N}$ mineralization or increased $\mathrm{N}$ availability for plant uptake. In fact, the microbial biomass $\mathrm{N}$ showed a significant positive correlation with $\mathrm{NH}_{4}^{+}-\mathrm{N}(\mathrm{r}=0.8669, \mathrm{p}<0.05)$, and $\mathrm{NO}_{3}^{-}-\mathrm{N}(\mathrm{r}=0.7512, \mathrm{p}<0.05)($ Table 3$)$.

Table 3. Bivariate correlation between soil properties and microbial properties $(n=54)$ computed using Pearson's coefficient ( $r)$.

\begin{tabular}{lccccc}
\hline Microbial properties & $\mathbf{p H}$ & $\mathbf{C E C}$ & Total N & $\mathbf{N H}_{4}{ }^{+}-\mathbf{N}$ & $\mathbf{N} \mathbf{3}_{3}^{-} \mathbf{N}$ \\
\hline nifH gene & $0.9681^{\star \star}$ & $0.9419^{\star \star}$ & $0.7439^{\star}$ & 0.5327 & 0.7467 \\
\hline nifH transcript & 0.5030 & 0.4102 & 0.0182 & -0.3294 & 0.0285 \\
\hline Urease & -0.3021 & -0.1414 & 0.2774 & 0.4618 & 0.1333 \\
\hline Microbial biomass N & $0.7281^{\star}$ & $0.8216^{\star}$ & $0.9177^{\star \star}$ & $0.8669^{\star}$ & $0.7512^{\star}$ \\
\hline
\end{tabular}

Note. ${ }^{*}$ Significant at $\mathrm{p}<0.05,{ }^{* *}$ significant at $\mathrm{p}<0.01$.

The microbial biomass C:N ratio could represent a more robust crop productivity indicator, where a high ratio would predict a low agronomic performance (Li et al. 2016). Previously reported data on microbial biomass C:N ratios in the same field site (Halmi et al. 2018) demonstrated that the biochar amendments significantly lowered the value of microbial biomass $\mathrm{C}: \mathrm{N}$ ratios during the first cycle. Meanwhile, the coapplication of fertilizer to biochar was able to further significantly shrink the microbial biomass $\mathrm{C}: \mathrm{N}$ ratios from the biochar treated plot (Halmi et al. 2018). A similar reduction of microbial biomass $\mathrm{C}: \mathrm{N}$ ratios following co-amendments of biochar with fertilizer in the humid tropics was also found by Oladele et al. (2019c). However, the combined effect of NPK fertilization on this ratio in the next two cycles cannot be verified as the data of microbial biomass $\mathrm{C}$ was not reported in the present study.

The biochar amendments did not affect the activity of urease in the tropical soil. An alteration of soil urease activity $(\mathrm{p}<0.05)$ was only observed during the first cropping cycle in all the NPK plots (Table 2). Changes of urease activity in the plots treated with biochar alone were not observed. However, the urease activities in $\mathrm{FPK}_{3 \mathrm{M}}$ and $\mathrm{FRH}_{3 \mathrm{M}}$ were not statistically different from $\mathrm{PK}_{3 \mathrm{M}}$ and $\mathrm{RH}_{3 \mathrm{M}}$ ( $\left.\mathrm{p}>0.05\right)$. Similarly, stimulation of urease activity following the coapplication of biochar with urea fertilizer was reported by Oladele (2019b) in a humid tropical alfisol by using a rice husk biochar. The stimulation of urease in plots incorporated with NPK fertilizer is attributed mainly to the urea input, which serves as the substrate for microbial urease hydrolytic activity. 


\section{Responses of diazotrophic population}

The total and active abundance of nifH involved in N2 fixation is shown in Fig. 1. At present, there is no reported field study concerning the biochar effect on the population of diazotrophs in the humid tropics. In fact, information on the nifH expression of the active diazotrophic population in biochar amended soil in other climatic regions is still limited. Absolute quantification of nifH genes (DNA-derived) and transcripts (RNA-derived) was conducted to enumerate the total and active diazotrophs, respectively. The DNA-based quantification reveals the total number of microbial populations harboring the nifH gene that may possess the potential to fix $\mathrm{N}_{2}$, while RNA-based quantification reflects the active functional population carrying out nitrogenase reduction activity of atmospheric N2 (Pereira e Silva et al. 2013; Poly et al. 2001). The complementary quantification approach of DNA and RNA-derived populations is vital to achieve a comprehensive overview of the total and active members in the N2 fixing functionality (Machuca and Salgar-Chaparro 2019).

(a)

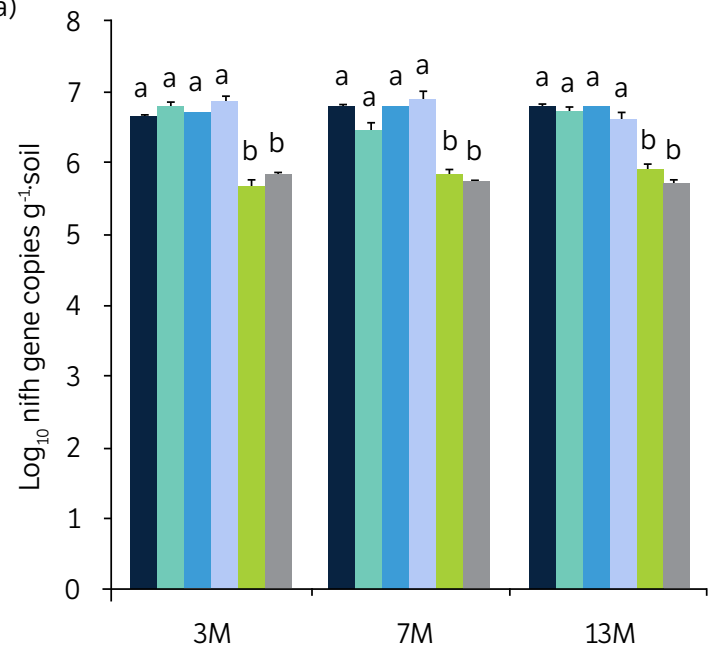

(b)

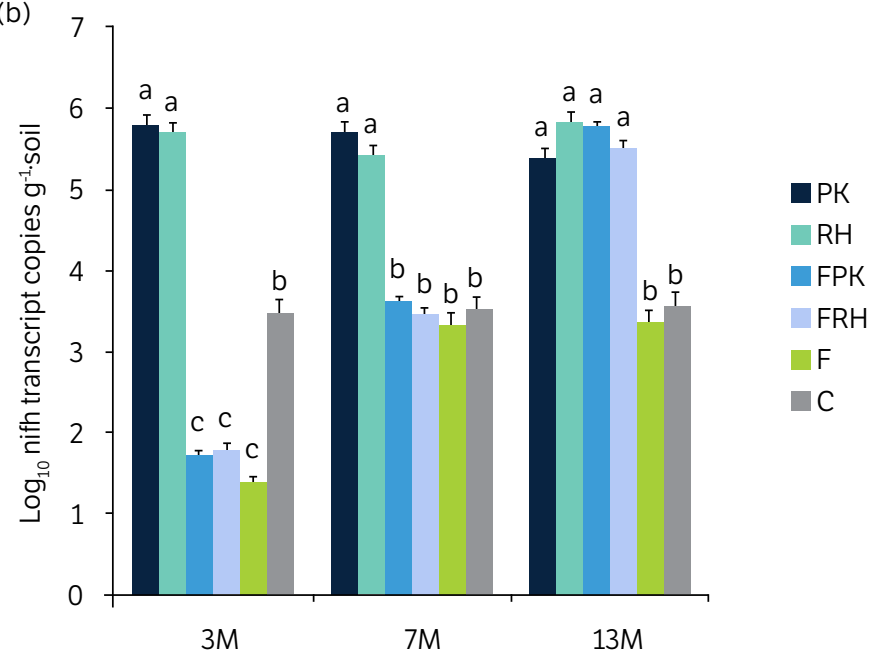

Figure 1. The abundance of (a) gene and (b) transcript copies of nifH in all treatments at $3(3 M), 7(7 M)$ and 13 months (13M) of field exposure. Note. Mean values indicated by different letters within a cropping cycle are statistically different at $p<0.05$ by Tukey's range test. Error bars represent standard deviation $(n=3)$.

The log value of total nifH abundance recorded in all soils treated with biochar, with or without fertilizer, was higher $(\mathrm{p}<0.05)$ than values obtained from control soils, signifying stimulation of the total diazotrophic population. The nifH gene abundance was equivalent between palm kernel shell and rice husk treated plots at all sampling times, with no statistical difference found in the statistical pair-wise comparison (Fig. 1a). Although data on diazotrophic populations response to biochar treatment have not been reported in the humid tropics, this finding was corroborated by the meta-analysis reported by Xiao et al. (2019), where biochar amendments had a significant stimulation effect on nifH gene abundance in the soil of various climatic regions. Correlation of the nifH gene abundance from qPCR amplification revealed strong positive linkages of total diazotrophs with soil $\mathrm{pH}(\mathrm{r}=0.9681$, $\mathrm{p}<0.01)$, and CEC $(\mathrm{r}=0.9419, \mathrm{p}<0.01)$ (Table 3$)$. The proliferation of total diazotrophs abundance can be associated with biochar ability to transform soil abiotic factors that regulate the soil biological processes, reflected by the increased soil $\mathrm{pH}$ and CEC enhancement. Modification of these abiotic factors has been proposed to indirectly enhance soil microbial habitat quality (Ameloot et al. 2013).

The transcript copy number of nifH expressed in all soils treated with biochar alone was higher $(\mathrm{p}<0.01)$ in all three cropping cycles. Supplementation of fertilizer reduced the active diazotrophic population in the soil during the first cropping cycle. A similar result was observed in biochar treated soil incorporated with fertilizer during the same cycle $\left(\mathrm{FPK}_{3 \mathrm{M}}\right.$ and $\mathrm{FRH}_{3 \mathrm{M}}$ ), where the nifH expression was lower than the control soil. The difference of the nifH transcript became insignificant in all plots with fertilizer in the following cycle compared to the control. During the last cycle, the nifH transcript in $\mathrm{FPK}_{13 \mathrm{M}}$ and $\mathrm{RH}_{13 \mathrm{M}}$ increased significantly from the control soil. The nifH transcript exhibited an 
inverse correlation with urease activity $(\mathrm{r}=-0.7178, \mathrm{p}<0.05)$, suggesting increasing urea hydrolysis and decreased $\mathrm{N}_{2}$ fixation. Nitrogen fertilization frequently inactivates the function of nifH, as reported in several studies (Crews et al. 2001; Cusack et al. 2009). Therefore, chemical N inputs used in the FPK and FRH treatments likely suppressed microbial nitrogenase expression (Reed et al. 2011; Pereira e Silva et al. 2013), hence, limiting the activity of $\mathrm{N}_{2}$ fixation by diazotrophic microorganisms in the soil.

This short-term study showed that both biochars promoted total and active diazotrophic populations. These results indicate that applying biochar to agricultural soils may help to reduce the reliance on chemical fertilization. Thus, biochar may serve as an environmentally friendly alternative soil amendment. However, further research is needed to verify whether biological $\mathrm{N}_{2}$ fixation by diazotrophic organisms alone resulting from biochar amendment is sufficient to meet the crop $\mathrm{N}$ demand and to promote agronomic performance. A combination of the ${ }^{15} \mathrm{~N}$ tracing method can be used to quantify the amounts of $\mathrm{N}_{2}$ fixed by the free-living diazotrophs. A meta-analysis conducted by Liu et al. (2018) pointed out a lack of study measuring biological $\mathrm{N}_{2}$ fixation by nonsymbiotic diazotrophs in biochar amended soils using this isotope technique.

\section{CONCLUSION}

The two types of biochar exhibited different $\mathrm{N}$ retention characteristics, and, depending on the particular nutrient demand, could serve as co-amendments to enhance fertilization efficiency in the humid tropics. Both biochar treatments stimulated the total and active diazotrophic soil population. However, a suppressive impact on diazotrophic N2 fixation functionality was observed from the chemical $\mathrm{N}$ fertilization even with biochar coapplication.

The overall data proposes two possible approaches for land management strategy in soils of the humid tropics. First, to reduce nutrient losses due to weathering, palm kernel shell and rice husk biochars can be coapplied with $\mathrm{N}$ fertilizer. Second, to reduce agricultural dependence on chemical fertilizers, soil can be amended with biochar alone, relying solely on the activity of diazotrophs. However, the second management option needs further investigation to elucidate the adequacy of biological N2 fixation to meet crops nutritional needs. Simultaneously, further field verification to establish the reliability and validity of these two practical management options should be evaluated in other soil types in the humid tropics.

\section{AUTHORS' CONTRIBUTION}

Conceptualization: Halmi M. F. A. and Simarani K.; Methodology: Halmi M. F. A. and Simarani K.; Investigation: Halmi M. F. A.; Writing - Original Draft: Halmi M. F. A.; Writing - Review and Editing: Halmi M. F. A. and Simarani K.; Funding Acquisition: Simarani K.; Resources: Simarani K.; Supervision: Simarani K.

\section{DATA AVAILABILITY STATEMENT}

Data will be available upon request.

\section{FUNDING}

University of Malaya

Grant No. RP023B-16SUS

PG057-2013A 


\section{ACKNOWLEDGMENTS}

The authors thank the University Malaya and Department of Chemistry Malaysia for providing research facilities.

\section{REFERENCES}

Alling, V., Hale, S. E., Martinsen, V., Mulder, J., Smebye, A., Breedveld, G. D. and Cornelissen, G. (2014). The role of biochar in retaining nutrients in amended tropical soils. Journal of Plant Nutrition and Soil Science, 177, 671-680. https://doi.org/10.1002/jpln.201400109

Ameloot, N., Graber, E. R., Verheijen, F. G. A. and De Neve, S. (2013). Interactions between biochar stability and soil organisms: review and research needs. European Journal of Soil Science, 64, 379-390. https://doi.org/10.1111/ejss.12064

Clough, T. J., Condron, L. M., Kammann, C. and Müller, C. (2013). A Review of Biochar and Soil Nitrogen Dynamics. Agronomy, 3, 275293. https://doi.org/10.3390/agronomy3020275

Crews, T. E., Kurina, L. M. and Vitousek, P. M. (2001). Organic matter and nitrogen accumulation and nitrogen fixation during early ecosystem development in Hawaii. Biogeochemistry, 52, 259-279. https://doi.org/10.1023/A:1006441726650

Cusack, D. F., Silver, W. and McDowell, W. H. (2009). Biological Nitrogen Fixation in Two Tropical Forests: Ecosystem-Level Patterns and Effects of Nitrogen Fertilization. Ecosystems, 12, 1299-1315. https://doi.org/10.1007/s10021-009-9290-0

Doyle, A., Weintraub, M. N. and Schimel, J. P. (2004). Persulfate Digestion and Simultaneous Colorimetric Analysis of Carbon and Nitrogen in Soil Extracts. Soil Science Society of America Journal, 68, 669-676. https://doi.org/10.2136/sssaj2004.6690

Gaskin, J. W., Steiner, C., Harris, K., Das, K. C. and Bibens, B. (2008). Effect of Low-Temperature Pyrolysis Conditions on Biochar for Agricultural Use. Transactions of the ASABE, 51, 2061-2069. https://doi.org/10.13031/2013.25409

Gillman, G. P. and Sumpter, E. A. (1986). Modification to the compulsive exchange method for measuring exchange characteristics of soils. Australian Journal of Soil Research, 24, 61-66. https://doi.org/10.1071/SR9860061

Hailegnaw, N. S., Mercl, F., Pračke, K., Száková, J. and Tlustoš, P. (2019). Mutual relationships of biochar and soil pH, CEC, and exchangeable base cations in a model laboratory experiment. Journal of Soils and Sediments, 19, 2405-2416. https://doi.org/10.1007/s11368-019-02264-z

Hale, S. E., Nurida, N. L., Mulder, J., Sørmo, E., Silvani, L., Abiven, S., Joseph, S., Taherymoosavi, S. and Cornelissen, G. (2020). The effect of biochar, lime and ash on maize yield in a long-term field trial in a Ultisol in the humid tropics. Science of the Total Environment, 719 , 137455. https://doi.org/10.1016/j.scitotenv.2020.137455

Halmi, M. F. A., Hasenan, S. N., Simarani, K. and Abdullah, R. (2018). Linking Soil Microbial Properties with Plant Performance in Acidic Tropical Soil Amended with Biochar. Agronomy, 8, 255. https://doi.org/10.3390/agronomy8110255

Halmi, M. F. A. and Simarani, K. (2021). Effect of two contrasting biochars on soil microbiota in the humid tropics of Peninsular Malaysia. Geoderma, 395, 115088. https://doi.org/10.1016/j.geoderma.2021.115088

Kandeler, E. and Gerber, H. (1988). Short-term assay of soil urease activity using colorimetric determination of ammonium. Biology and Fertility of Soils, 6, 68-72. https://doi.org/10.1007/BF00257924

Lehmann, J., Rillig, M. C., Thies, J., Masiello, C. A., Hockaday, W. C. and Crowley, D. (2011). Biochar effects on soil biota - A review. Soil Biology and Biochemistry, 43, 1812-1836. https://doi.org/10.1016/j.soilbio.2011.04.022

Li, Y., Wu, J., Shen, J., Liu, S., Wang, C., Chen, D., Huang, T. and Zhang, J. (2016). Soil microbial C:N ratio is a robust indicator of soil productivity for paddy fields. Scientific Reports, 6, 35266. https://doi.org/10.1038/srep35266 
Liu, Q., Zhang, Y., Liu, B., Amonette, J. E., Lin, Z., Liu, G., Ambus, P. and Xie, Z. (2018). How does biochar influence soil N cycle? A metaanalysis. Plant and Soil, 426, 211-225. https://doi.org/10.1007/s11104-018-3619-4

Machuca, L. L. and Salgar-Chaparro, S. J. (2019). Complementary DNA/RNA-Based Profiling: Characterization of Corrosive Microbial Communities and Their Functional Profiles in an Oil Production Facility. Frontiers in Microbiology, 10, 2587. https://doi.org/10.3389/ fmicb.2019.02587

Moura, E. G., Gehring, C., Braun, H., Ferraz Junior, A. S. L., Reis, F. O. and Aguiar, A. C. F. (2016). Improving Farming Practices for Sustainable Soil Use in the Humid Tropics and Rainforest Ecosystem Health. Sustainability, 8, 841. https://doi.org/10.3390/su8090841

Oladele, S. O. (2019b). Effect of biochar amendment on soil enzymatic activities, carboxylate secretions and upland rice performance in a sandy clay loam Alfisol of Southwest Nigeria. Scientific African, 4, e00107. https://doi.org/10.1016/j.sciaf.2019.e00107

Oladele, S. O., Adeyemo, A. J. and Awodun, M. A. (2019a). Influence of rice husk biochar and inorganic fertilizer on soil nutrients availability and rain-fed rice yield in two contrasting soils. Geoderma, 336, 1-11. https://doi.org/10.1016/j.geoderma.2018.08.025

Oladele, S., Adeyemo, A., Adegaiye, A. and Awodun, M. (2019c). Effects of biochar amendment and nitrogen fertilization on soil microbial biomass pools in an Alfisol under rain-fed rice cultivation. Biochar, 1, 163-176. https://doi.org/10.1007/s42773-019-00017-2

Pereira e Silva, M. C., Schloter-Hai, B., Schloter, M., van Elsas, J. D. and Salles, J. F. (2013). Temporal Dynamics of Abundance and Composition of Nitrogen-Fixing Communities across Agricultural Soils. PLoS One, 8, e74500. https://doi.org/10.1371/journal.pone.0074500

Petter, F. A., Leite, L. F. C., Machado, D. M., Marimon Júnior, B. H., Lima, L. B., Freddi, O. S. and Araújo, A. S. F. (2019). Microbial biomass and organic matter in an oxisol under application of biochar. Bragantia, 78, 109-118. https://doi.org/10.1590/1678-4499.2018237

Poly, F., Ranjard, L., Nazaret, S., Gourbière, F. and Monrozier, L. J. (2001). Comparison of nifH Gene Pools in Soils and Soil Microenvironments with Contrasting Properties. Applied and Environmental Microbiology, 67, 2255-2262. https://doi.org/10.1128/AEM.67.5.2255-2262.2001

Reed, S. C., Cleveland, C. C. and Townsend, A. R. (2011). Functional Ecology of Free-Living Nitrogen Fixation: A Contemporary Perspective. Annual Review of Ecology, Evolution, and Systematics, 42, 489-512. https://doi.org/10.1146/annurev-ecolsys-102710-145034

Rösch, C., Mergel, A. and Bothe, H. (2002). Biodiversity of Denitrifying and Dinitrogen-Fixing Bacteria in an Acid Forest Soil. Applied and Environmental Microbiology, 68, 3818-3829. https://doi.org/10.1128/AEM.68.8.3818-3829.2002

Sanford, J. R., Larson, R. A. and Runge, T. (2019). Nitrate sorption to biochar following chemical oxidation. Science of The Total Environment, 669, 938-947. https://doi.org/10.1016/j.scitotenv.2019.03.061

Simarani, K., Halmi, M. F. A. and Abdullah, R. (2018). Short-term effects of biochar amendment on soil microbial community in humid tropics. Archives of Agronomy and Soil Science, 64, 1847-1860. https://doi.org/10.1080/03650340.2018.1464149

Tomczyk, A., Sokołowska, Z. and Boguta, P. (2020). Biochar physicochemical properties: pyrolysis temperature and feedstock kind effects. Reviews in Environmental Science and Bio/Technology, 19, 191-215. https://doi.org/10.1007/s11157-020-09523-3

Uttran, A., Loh, S. K., Kong, S. H. and Bachmann, R. T. (2018) Adsorption of NPK Fertilizer and Humic Acid on Palm Kernel Shell Biochar. Journal of Oil Palm Research, 30, 472-484. https://doi.org/10.21894/jopr.2018.0029

Vance, E. D., Brookes, P. C. and Jenkinson, D. S. (1987). An extraction method for measuring soil microbial biomass C. Soil Biology and Biochemistry, 19, 703-707. https://doi.org/10.1016/0038-0717(87)90052-6

Xiao, Z., Rasmann, S., Yue, L., Lian, F., Zou, H. and Wang, Z. (2019). The effect of biochar amendment on N-cycling genes in soils: A metaanalysis. Science of the Total Environment, 696, 133984. https://doi.org/10.1016/j.scitotenv.2019.133984 